\title{
SOUTH-WEST ATLANTIC RIGHT WHALES EUBALAENA AUSTRALIS (DESMOULINS, 1822) DISTRIBUTION NEARBY THE MAGELLAN STRAIT
}

\author{
DISTRIBUCIÓN DE LA BALLENA FRANCA EUBALAENA AUSTRALIS (DESMOULINS, \\ 1822) DEL ATLÁNTICO SUROCCIDENTAL CERCA DEL ESTRECHO DE MAGALLANES
}

\author{
Jimena Belgrano1, Miguel Iñíguez ${ }^{1, \text { II }}$, Jorge Gibbons ${ }^{\text {III, IV }}$, Cristian Garcíalll \& Carlos Olavarría ${ }^{\text {IV }}$
}

Southern right whales Eubalaena australis (Desmoulins, 1822) ${ }^{1}$ formerly occurred in very large numbers in the Southern Hemisphere, particularly in coastal waters of the southern part of Australia, New Zealand, American and African continents, as well as in most of the islands between $30^{\circ} \mathrm{S}$ and $60^{\circ} \mathrm{S}$ (Townsend 1935, Matthews 1938, Dakin 1963). It has been estimated that by the beginning of its exploitation (late XVIII century), there were between 60,000 and 160,000 individuals. However, severe depletion of this species by commercial whaling may have reached as low as 200-300 individuals by 1920 (Anonymous 2001, Jackson et al. 2007).

Off both Pacific and Atlantic coast of South America southern right whales were caught extensively (Townsend 1935). Historical whaling accounts from Chile referred to a well known catching ground called the "Coast of Chile Ground". This stock of whales seems have been distributed between $30^{\circ} \mathrm{S}$ and $50^{\circ} \mathrm{S}$ (Townsend 1935). Based on the logbooks

1 The taxonomy of right whales has been discussed in recent years. Rice (1998) proposed all right whales species plus the bowhead belonged to the genus Balaena Linnaeus, 1758. However, genetic evidence supported the earlier separation retaining the scientific name Eubalaena australis (Desmoulins, 1822) for the southern hemisphere right whale (Rosembaum et al. 2000). of Yankee and French whalers, and on Chilean whaling catch data it has been estimated that around 9,000 individuals were hunted there between 1785 and 1976 (Aguayo-Lobo et al. submitted ${ }^{2}$ ). Along the Atlantic coast of South America, southern right whales were caught off southern Brazil, and along Uruguay and Argentina coasts south to Tierra del Fuego, with a large proportion of whales obtained offshore in the so called "Brazil" and "False" banks (Townsend 1935). It is estimated that 29,568 southern right whales were caught in the Brazil bank between 1772 and 1812 (Richards 1994).

Unlike in the South-East Pacific, where a slow recovery of the southern right whales population has been supported by the increasing number of sightings and extended distribution north up to Perú (AguayoLobo \& Torres 1986, Aguayo-Lobo et al. 1992 , Van Waerebeek et al. 1992, Van Waerebeek et al. 1998, Santillán et al. 2004, Olavarría et al. 2005²,

2 Aguayo-Lobo A., J. Acevedo, J.L. Brito, C. Olavarría, R. Moraga \& C. Olave submitted. La ballena franca de sur, Eubalaena australis (Desmoulins 1822) en aguas chilenas: análisis de sus registros desde 1976 a 2008. Revista de Biología Marina y Oceanografía.

3 Olavarría C., M. Flores \& R. Moraga 2005. Update on the eastern South Pacific southern right whale population. Report SC/7/BRG12 to the Scientific Committee of the International Whaling Commission. Ulsan, Korea. 30 May - 10 June.

I Fundación Cethus. Potosí 2087, Olivos, Buenos Aires, Argentina. jimena.belgrano@cethus.org, miguel.iniguez@cethus.org

II Whale and Dolphin Conservation Society. Brookfield House, Chippenham, United Kingdom.

III Laboratorio de Zoología, Instituto de la Patagonia, Universidad de Magallanes Punta Arenas, Chile. jorgegibbons@gmail.com

Iv Fundación Centro de Estudios del Cuaternario Fuego-Patagonia y Antártica (CEQUA). Punta Arenas, Chile. carlos.olavarria@cequa.cl 
Aguayo-Lobo et al. submitted), in the South-West Atlantic it has been documented a steady recovery, particularly for Península Valdés, Argentina (Payne et al. 1990, Cooke et al. 2001), but also for Brazil (Castello \& Pinedo 1979, de Oliveira Santos et al. 2001, Groch et al. 2005) and Uruguay (Piedra et al. 2006, Costa et al. 2007). Southern right whales have been recorded particularly in the southern part of Argentina (Santa Cruz province) (Goodall \& Galeazzi 1986, Pérez et al. 1995, Tossenberger et al. 20004, Iñíguez et al. 20035 , Belgrano et al. $2008^{6}$ ), where some whales have been observed entering the Chilean Magellan Strait waters. Gibbons et al. (2006) analyzed contemporary sighting and stranding data of this species in the southern Chilean fjords finding that it only distributes at the central and eastern parts of the Magellan Strait and Beagle channel. Given the closest proximity to the range of the South Atlantic population, these whales were assumed to correspond with that population rather than with the South-East Pacific off Chile-Perú.

In this note we review the distribution of southern right whales in the area nearby the eastern entrance to the Magellan Strait, considering records from the nearby province of Santa Cruz, Argentina (Iñíguez et al. 2003) and the southern Chilean fjords (Gibbons et al. 2006), additionally to unreported records in both areas, with the aim of examining the local distribution of the species across the border between Argentina and Chilean waters.

In the area of Santa Cruz, Argentina, sightings have been recorded since 1986 . We include here those records nearby Cabo Vírgenes and Punta Dungeness as in Iñíguez et al. (2003), as well as new records from further research undertaken in the area by Fundación Cethus since 2004. In the Chilean Patagonian and Fuegian channels and

\footnotetext{
Tossenberger V.P., M.A. Iñíguez \& C.M. Pozzi 2000. Varamiento y rescate de una ballena franca austral (Eubalaena glacialis australis) en la Ria de Santa Cruz, Pcia. Santa Cruz, Argentina. In "9" Reunión de Trabajo de Especialistas en Mamíferos Acuáticos de América del Sur y $3^{\circ}$ Congreso de SOLAMAC." Buenos Aires, Argentina.

Iñíguez M., J. Belgrano, A. Tomsin, C. de Haro, C. Gribaudo \& V. Tossenberg 2003. Sightings and stranding of southern right whales (Eubalaena australis) off Santa Cruz, Patagonia, Argentina (19862003). Report SC/55/BRG8 to the Scientific Committee of the International Whaling Commission. Berlin, Germany 26 May - 6 June, 2003.

6 Belgrano J., C. Gribaudo, D. Arcucci, F. Kröhling \& M. Iñíguez 2008. Recent increase in the number of Southern right whales (Eubalaena australis) in Golfo San Jorge, Santa Cruz, Patagonia Argentina. Report SC/60/BRG4 to the Scientific Committee of the International Whaling Commission. Santiago, Chile. 1 - 10 June.
}

fjords, extensive surveys for cetaceans have been undertaken between 1997 and 2005 as in Gibbons et al. (2006). Further surveys have been undertaken by the Centre for Quaternary Research (CEQUA) in the fjords and channels at the central and western portions of the Magellan Strait, as well as in southern channels between 2003 and 2008.

Sixty-nine sightings of southern right whales have been recorded in the study area from 1985 and every year of the last nine years (Fig. 1, Table 1). Most of them have been concentrated in the Cabo Vírgenes area, with fewer in Punta Dungeness and in the central and eastern portions of the Magellan Strait. Most of the sightings were recorded during January, February and April, however this may be correlated to the greater sighting effort occurred in these months (data not shown).

The available data supports that the area nearby the eastern entrance of the Magellan Strait, including Cabo Vírgenes and Punta Dungeness, is used by southern right whales in recent times, similar to what occurred during early stages of commercial whaling by the distribution of Yankee whalers catches in the surrounding area (Townsend 1935). The apparent increasing in sightings from 90's decade might reflect the steady recovery of the South Atlantic population (Payne et al. 1990, Cooke et al. 2001), given that the eastern area of the Magellan Strait was extensively surveyed by experienced researchers searching for Commerson's dolphins that did not observed southern right whales there (Venegas \& Atalah 1987, Leatherwood et al. 1988, Venegas 1996, Lescrauwaet et al. 2000).

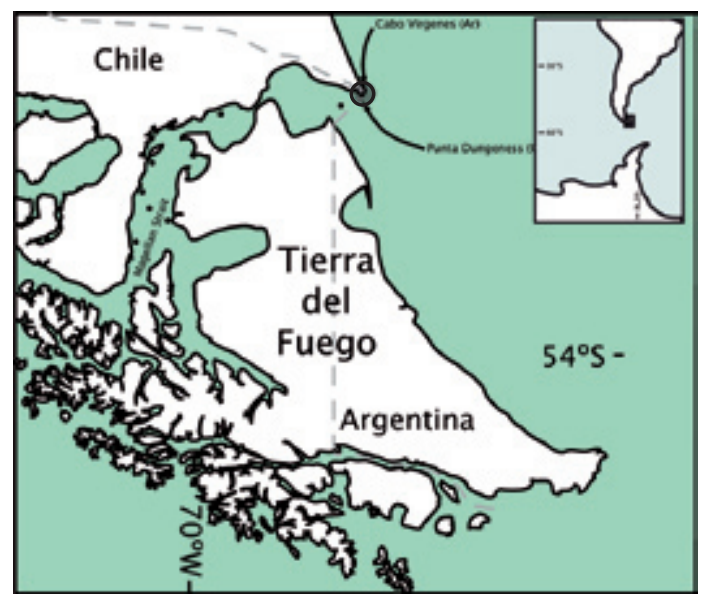

Fig. 1. Distribution of southern right whales nearby the eastern entrance to the Magellan Strait. 
TABLE 1. Sightings of southern right whales nearby the eastern entrance to the Magellan Strait.

\begin{tabular}{|c|c|c|c|}
\hline Date & Location & $\mathbf{N}$ & Source \\
\hline 11-11-1985 & Laredo Bay & 1 & Gibbons et al. 2006 \\
\hline $26-12-1986$ & Cabo Vírgenes 52¹9’59.8”S; 68²1'20.7”W & 1 & Pérez et al. 1995 \\
\hline 26-1-1994 & Cabo Vírgenes 52¹9’59.8”S; 68²1'20.7”W & 1 & Iñíguez et al. 2003 \\
\hline 27-1-1994 & Cabo Vírgenes 52¹9’59.8”S; 68²1'20.7”W & 1 & Iñíguez et al. 2003 \\
\hline $5-2-1994$ & Cabo Vírgenes 52¹9’59.8”S; 68²1'20.7”W & 1 & Iñíguez et al. 2003 \\
\hline $6-2-1994$ & Cabo Vírgenes 52¹9’59.8”S; 68²1’20.7”W & 1 & Iñíguez et al. 2003 \\
\hline $5-2-1995$ & Cabo Vírgenes 52¹9’59.8”S; 68²1'20.7”W & 4 (1 calf) & Iñíguez et al. 2003 \\
\hline $5-2-1995$ & Cabo Vírgenes 52¹9’59.8”S; 68²1’20.7”W & 1 & Iñíguez et al. 2003 \\
\hline $5-2-1995$ & Cabo Vírgenes 52¹9’59.8”S; 68²1’20.7”W & 2 & Iñíguez et al. 2003 \\
\hline $6-2-1995$ & Cabo Vírgenes 52¹9’59.8”S; 68²1'20.7”W & 2 & Iñíguez et al. 2003 \\
\hline $12-2-1995$ & Cabo Vírgenes 52॰19’59.8”S; 68²1’20.7”W & 1 & Iñíguez et al. 2003 \\
\hline $17-2-2000$ & Pingüinera Cabo Vírgenes $52^{\circ} 22^{\prime} \mathrm{S}$; $68^{\circ} 25^{\prime} \mathrm{W}$ & 1 & Iñíguez et al. 2003 \\
\hline $6-3-2000$ & Pingüinera Cabo Vírgenes $52^{\circ} 22^{\prime} \mathrm{S}$; $68^{\circ} 25^{\prime} \mathrm{W}$ & 1 & Iñíguez et al. 2003 \\
\hline $10-3-2000$ & Pingüinera Cabo Vírgenes $52^{\circ} 22^{\prime} \mathrm{S} ; 68^{\circ} 25^{\prime} \mathrm{W}$ & 1 & Iñíguez et al. 2003 \\
\hline 1 to $21-4-2000$ & Pingüinera Cabo Vírgenes $52^{\circ} 22^{\prime} \mathrm{S} ; 6^{\circ} 25^{\prime} \mathrm{W}$ & 1 to 4 per day & Iñíguez et al. 2003 \\
\hline 20 to $25-07-2000$ & Boca Estrecho Magallanes $52^{\circ} 30^{\prime} \mathrm{S} ; 6^{\circ} 28^{\prime} \mathrm{W}$ & up to 11 & Iñíguez et al. 2003 \\
\hline 26 to $28-7-2000$ & Pingüinera Cabo Vírgenes $52^{\circ} 22^{\prime} S$; $68^{\circ} 25^{\prime} \mathrm{W}$ & 5 & Iñíguez et al. 2003 \\
\hline 28-1-2001 & Pingüinera Cabo Vírgenes $52^{\circ} 22^{\prime} \mathrm{S} ; 68^{\circ} 25^{\prime} \mathrm{W}$ & 2 & Iñíguez et al. 2003 \\
\hline $12-2-2001$ & Pingüinera Cabo Vírgenes $52^{\circ} 22^{\prime} \mathrm{S} ; 68^{\circ} 25^{\prime} \mathrm{W}$ & 2 & Iñíguez et al. 2003 \\
\hline $13-4-2001$ & Cabo Vírgenes $52^{\circ} 19^{\prime} 59.8^{\prime \prime S}$; 68²1’20.7”W & 1 & Iñíguez et al. 2003 \\
\hline $13-4-2001$ & Cabo Vírgenes 52¹9’59.8”S; 68²1’20.7”W & 3 & A. Verner. This report \\
\hline $14-4-2001$ & Cabo Vírgenes 52¹9’59.8”S; 68²1’20.7”W & 3 & A. Verner. This report \\
\hline $14-4-2001$ & Cabo Vírgenes 52¹9’59.8”S; 68²1’20.7”W & 1 & Iñíguez et al. 2003 \\
\hline $14-4-2001$ & Boca Estrecho Magallanes $52^{\circ} 30^{\prime} \mathrm{S} ; 68^{\circ} 28^{\prime} \mathrm{W}$ & 1 & Suarez. This report \\
\hline $17-4-2001$ & Cabo Vírgenes 52¹9’59.8”S; 68²1'20.7”W & 1 & Iñíguez et al. 2003 \\
\hline $14-1-2002$ & Pingüinera Cabo Vírgenes $52^{\circ} 22^{\prime} \mathrm{S} ; 6^{\circ} 25^{\prime} \mathrm{W}$ & 1 & Iñíguez et al. 2003 \\
\hline $1-2-2002$ & Dungeness & 1 & Gibbons et al. 2006 \\
\hline $7-2-2002$ & Pingüinera Cabo Vírgenes $52^{\circ} 22^{\prime} \mathrm{S} ; 6^{\circ} 25^{\prime} \mathrm{W}$ & 1 & Iñíguez et al. 2003 \\
\hline $1-4-2002$ & Pingüinera Cabo Vírgenes $52^{\circ} 22^{\prime} \mathrm{S}$; $68^{\circ} 25^{\prime} \mathrm{W}$ & 3 & Iñíguez et al. 2003 \\
\hline $1-4-2002$ & Pingüinera Cabo Vírgenes $52^{\circ} 22^{\prime} \mathrm{S}$; $68^{\circ} 25^{\prime} \mathrm{W}$ & 2 & Iñíguez et al. 2003 \\
\hline 3-4-2002 & Pingüinera Cabo Vírgenes $52^{\circ} 22^{\prime} \mathrm{S} ; 6^{\circ} 25^{\prime} \mathrm{W}$ & 3 & Iñíguez et al. 2003 \\
\hline $6-4-2002$ & Pingüinera Cabo Vírgenes $52^{\circ} 22^{\prime} \mathrm{S} ; 68^{\circ} 25^{\prime} \mathrm{W}$ & 2 & Iñíguez et al. 2003 \\
\hline $12-4-2002$ & Pingüinera Cabo Vírgenes $52^{\circ} 22^{\prime} S$; $68^{\circ} 25^{\prime} \mathrm{W}$ & 4 & Iñíguez et al. 2003 \\
\hline $12-4-2002$ & Pingüinera Cabo Vírgenes $52^{\circ} 22^{\prime} \mathrm{S} ; 68^{\circ} 25^{\prime} \mathrm{W}$ & 2 & Iñíguez et al. 2003 \\
\hline $13-4-2002$ & Pingüinera Cabo Vírgenes $52^{\circ} 22^{\prime} \mathrm{S}$; $68^{\circ} 25^{\prime} \mathrm{W}$ & 1 (1 calf) & Iñíguez et al. 2003 \\
\hline $18-4-2002$ & Boca Estrecho Magallanes $52^{\circ} 30^{\prime} \mathrm{S} ; 6^{\circ} 28^{\prime} \mathrm{W}$ & 2 & Iñíguez et al. 2003 \\
\hline 22-4-2002 & Pingüinera Cabo Vírgenes $52^{\circ} 22^{\prime} \mathrm{S}$; $68^{\circ} 25^{\prime} \mathrm{W}$ & 1 & Iñíguez et al. 2003 \\
\hline $6-6-2002$ & Pingüinera Cabo Vírgenes $52^{\circ} 22^{\prime} \mathrm{S}$; $68^{\circ} 25^{\prime} \mathrm{W}$ & 2 & Iñíguez et al. 2003 \\
\hline $22-6-2002$ & Pingüinera Cabo Vírgenes $52^{\circ} 22^{\prime} \mathrm{S}$; $68^{\circ} 25^{\prime} \mathrm{W}$ & 7 & Iñíguez et al. 2003 \\
\hline $30-6-2002$ & Boca Estrecho Magallanes $52^{\circ} 30^{\prime} \mathrm{S} ; 68^{\circ} 28^{\prime} \mathrm{W}$ & 5 & Iñíguez et al. 2003 \\
\hline $30-6-2002$ & Boca Estrecho Magallanes $52^{\circ} 30^{\prime} \mathrm{S} ; 68^{\circ} 28^{\prime} \mathrm{W}$ & 3 & Hugo Menichelli. This report \\
\hline $4-2-2003$ & Cabo Vírgenes 52¹9’59.8”S; 68²1'20.7”W & 2 & Iñíguez et al. 2003 \\
\hline $6-2-2003$ & Cabo Vírgenes 52¹9’59.8”S; 68²1'20.7”W & 2 & Iñíguez et al. 2003 \\
\hline 25 to $27-6-2003$ & Between Daniel \& Catalina Point & 30 (groups of $1-3$ ) & Gibbons et al. 2006 \\
\hline $1-8-2003$ & Dungeness & $2-3$ & Gibbons et al. 2006 \\
\hline $24-1-2004$ & Cabo Vírgenes 52¹9’59.8”S; 68²1’20.7”W & 1 & Fundación Cethus. This report \\
\hline $25-1-2004$ & Cabo Vírgenes 52¹9’59.8”S; 68²1’20.7”W & 2 & Fundación Cethus. This report \\
\hline $25-1-2004$ & Cabo Vírgenes 52¹9’59.8”S; 68²1’20.7”W & 1 & Fundación Cethus. This report \\
\hline $26-1-2004$ & Cabo Vírgenes 52¹9’59.8”S; 68²1’20.7”W & 2 & Fundación Cethus. This report \\
\hline $26-1-2004$ & Cabo Vírgenes 52¹9’59.8”S; 68²1'20.7”W & 5 & Fundación Cethus. This report \\
\hline
\end{tabular}




\begin{tabular}{|c|c|c|c|}
\hline $27-1-2004$ & Cabo Vírgenes $52^{\circ} 19^{\prime} 59.8^{\prime \prime S}$; 68²1’20.7”W & 1 & Fundación Cethus. This report \\
\hline 27-1-2004 & Cabo Vírgenes $52^{\circ} 19^{\prime} 59.8^{\prime \prime S}$; 68²1'20.7”W & 2 & Fundación Cethus. This report \\
\hline 27-9-2004 & Punta Arenas & 1 calf & Gibbons et al. 2006 \\
\hline 29-3-2005 & Dungeness & 1 & Gibbons et al. 2006 \\
\hline $9-9-2005$ & Paso Ancho $53^{\circ} 13^{\prime} \mathrm{S} ; 70^{\circ} 41^{\prime} \mathrm{W}$ & 1 & Gibbons et al. 2006 \\
\hline $11-9-2005$ & $30 \mathrm{kms}$ south of Punta Arenas & 2 ( 1 calf $)$ & Gibbons et al. 2006 \\
\hline $13-9-2005$ & Paso Ancho $53^{\circ} 28^{\prime} \mathrm{S} ; 70^{\circ} 29^{\prime} \mathrm{W}$ & 1 & Gibbons et al. 2006 \\
\hline $14-5-2006$ & Cabo Vírgenes 52¹9’59.8”S; 68²1’20.7”W & 1 & Fundación Cethus. This report \\
\hline $14-5-2006$ & Pingüinera Cabo Vírgenes $52^{\circ} 22^{\prime} \mathrm{S} ; 6^{\circ} 25^{\prime} \mathrm{W}$ & 1 & Fundación Cethus. This report \\
\hline $14-5-2006$ & Pingüinera Cabo Vírgenes $52^{\circ} 22^{\prime} \mathrm{S} ; 68^{\circ} 25^{\prime} \mathrm{W}$ & 2 & Fundación Cethus. This report \\
\hline $1-6-2006$ & San Gregorio Bay & 1 & Gibbons et al. 2006 \\
\hline May-07 & Dungeness & & Eduardo Barros. This report \\
\hline Jun-07 & Cabo Vírgenes $52^{\circ} 19^{\prime} 59.8^{\prime \prime S}$; 68²1’20.7”W & $\begin{array}{l}11 \text { individuals (not } \\
\text { sure composition }\end{array}$ & Jorge Perancho. This report \\
\hline $12-7-2007$ & Dungeness & & $\begin{array}{c}\text { Chilean Navy Lighthouse } \\
\text { personel. This report }\end{array}$ \\
\hline $26-1-2008$ & Cabo Vírgenes 52¹9’59.8”S; 68²1’20.7”W & 1 (1 calf) & Fundación Cethus. This report \\
\hline $30-1-2008$ & Boca Estrecho Magallanes $52^{\circ} 30^{\prime} \mathrm{S} ; 68^{\circ} 28^{\prime} \mathrm{W}$ & 1 & Fundación Cethus. This report \\
\hline $2-2-2008$ & Boca Estrecho Magallanes $52^{\circ} 30^{\prime} \mathrm{S} ; 68^{\circ} 28^{\prime} \mathrm{W}$ & 2 (1 calf) & Fundación Cethus. This report \\
\hline Jun-08 & Dungeness & 3 (1 calf) & $\begin{array}{c}\text { Chilean Navy Lighthouse } \\
\text { personel. This report }\end{array}$ \\
\hline Jul-08 & Dungeness & & Thomas Colnot. This report \\
\hline
\end{tabular}

From a local management perspective, in Chile two distinct management units should be considered when evaluating southern right whales, the Chile-Perú stock distributed off Pacific coast and the South Atlantic stock that distributes along the Magellan Strait and the Beagle Channel. This has not been clear in the past as a small portion of whales reported for Chile were in fact caught nearby the South-West Atlantic south of Tierra del Fuego and near the eastern entrance of the Magellan Strait, likely including whales from that ocean basin and incorrectly assigning them to the South-East Pacific Chile-Perú stock. Despite extensive effort in western areas of Magellan Strait and Patagonian and Fueguian channels, no southern right whales have been observed there (Gibbons et al. 2006, Jorge Acevedo, comm. pers., CEQUA unpublished data), supporting the hypothesis that the whales observed in the eastern part of the Magellan Strait correspond to the South Atlantic population (Gibbons et al. 2006). Moreover, the hiatus in the distribution across southern South America makes likely a reduced demographic interchange between both South-East Pacific and South Atlantic populations.

The study area seems to have a high potential for commercial activities related to whale watching on southern right whales from shore as it occurs in several locations along the south Atlantic coast of South America, notably Península Valdés (Hoyt \& Iñíguez 2008). Moreover, in Chile this is the location with more potential for this type of activity given the presence of the species is relatively regular. However, for a fully development of whale watching several biological and ecological aspects, such as habitat use at small scale and seasonal distribution patterns should be studied. Further systematic surveys are possible to undertake from the shore nearby Punta Dungeness, where Chilean Navy personnel from the lighthouse as well as "estancias" farmers report that they regularly observe whales from the shore. A coordinated systematic survey at Cabo Vírgenes will provide a more complete understanding of the southern right whales at the eastern entrance of the Magellan Strait.

\section{ACKNOWLEDGMENTS}

In Argentina we thank Prefectura Naval Argentina and Cristian de Haro for assistance in the field and providing information. JB and MI were financially supported by the Whale and Dolphin Conservation Society (United Kingdom), Cetacean Society International (USA) and the Humane Society of the United States (USA). Petrobras Energía 
also financially supported JB. Fundación Cethus research was undertaken under permits issued by the Subsecretaría de Medio Ambiente and the Dirección de Recursos Naturales, Consejo Agrario Provincial, Provincia de Santa Cruz, Argentina. In Chile we thank Jorge Acevedo for providing the information on CEQUA surveys. The work of JG in Chile was partially supported by grants from the "Acción Integrada Universidad Complutense de Madrid - Universidad de Magallanes", FONDEMA Código BIP 30059585-0 and FONDECYT 1020004. We are grateful to Jaime Cárcamo, José Zamorano and Fernando López Mirones for fieldwork assistance.

\section{LITERATURE CITED}

Aguayo-Lobo A., J.C. Cardenas \& D. Torres 1992. Análisis de los avistamientos de Eubalaena australis (Desmoulins, 1822) en aguas chilenas, desde 1983 hasta 1989. Serie Científica INACH 42 77-91.

Aguayo-Lobo A. \& D. Torres 1986. Records of the southern right whale Eubalaena australis (Desmoulins, 1822) from Chile between 1976 and 1982. In: Right whales: past and present status. (R. L. Brownell Jr, P. B. Best \& J. H. Prescott, Eds.), pp. 159-160. Report of the International Whaling Commission (Special issue 10), Cambridge.

Anonymous 2001. Report of the workshop on the comprehensive assessment of right whales: a worldwide comparison. In: Right whales: worldwide status. (P. B. Best, J. L. Bannister, R. L. Brownell Jr. \& G. P. Donovan, Eds.), pp. 1-60. Journal of Cetacean Research and Management, Cambridge.

Castello H.P. \& M.C. Pinedo 1979. Southern right whales (Eubalaena australis) along the southern Brazilian coast. Journal of Mammalogy 60 (2): 429-430.

Cooke J.G., V.J. Rowntree \& R. Payne 2001. Estimates of demographic parameters for southern right whales (Eubalaena australis) observed off Peninsula Valdes, Argentina. Journal of Cetacean Research and Management Special Issue 2 125-132.

Costa P., M. Piedra, P. Franco \& E. Páez 2007. Distribution and habitat use patterns of southern right whales, Eubalaena australis, off
Uruguay. Journal of Cetacean Management and Research 9 (1): 45-51.

Dakin W.J. 1963. Whalemen adventures. The story of whaling in Australian waters and other Southern seas related thereto, from the days of sails to modern times. Sirius Books, Sydney.

de Oliveira Santos M.C., S. Siciliano, S. de Souza Pacheco \& J.L. Altmayer Pizzorino 2001. Occurrence of southern right whales (Eubalaena australis) along southeastern Brazil. Journal of Cetacean Research and Management Special Issue 2: 153-156.

Gibbons J., J.J. Capella, A. Kusch \& J. Cárcamo 2006. The southern right whale Eubalaena australis (Desmoulins, 1822) in the Strait of Magellan, Chile. Anales Instituto Patagonia (Chile) 34: 75-80.

Goodall R.N.P. \& A.R. Galeazzi 1986. Recent sightings and strandings of southern right whales off subantarctic South America and the Antarctic Peninsula. In: Right whales: past and present status. (R. L. Brownell Jr, P. B. Best \& J. H. Prescott, Eds.), pp. 173-176. Report of the International Whaling Commission (Special issue 10), Cambridge.

Groch K.R., J.T. Palazzo Jr., P.A.C. Flores, F.R. Adler \& M.E. Fabian 2005. Recent increases in the right whale (Eubalaena australis) population off southern Brazil. Latin American Journal of Aquatic Mammals 4 (1): 41-47.

Hoyt E. \& M. Iñíguez 2008. Estado del Avistamiento de Cetáceos en América Latina, pp. 60. WDCS, Chippenham, UK; IFAW, East Falmouth, USA; Global Ocean, Londres, UK.

Jackson J.A., N.J. Patenaude, E.m.L. Carroll \& C.S. Baker 2007. How few whales were there after whaling? Inference from contemporary mtDNA diversity. Molecular Ecology.

Leatherwood S., R.A. Kastelein \& K.W. Miller 1988. Observations of Commerson's dolphin and other cetaceans in southern Chile, January-February 1984. . Report of the International Whaling Commission (Special Issue) 9: 71-83.

Lescrauwaet A.-C., J. Gibbons, L. Guzman \& A. Schiavini 2000. Abundance estimation of Commerson's dolphin in the eastern area of 
the Strait of Magallan-Chile. Revista Chilena de Historia Natural 73: 473-478.

Matthews L.H. 1938. Notes on the southern right whale, Eubalaena australis. Discovery Reports 17: 169-182.

Payne R., V. Rowntree, J.S. Perkins, J.G. Cooke \& K. Lankester 1990. Population size trends and reproductive parameters of right whales (Eubalaena australis) off Peninsula Valdez, Argentina. Report of the International Whaling Commission 12 271-278.

Pérez F., P. Sutton \& A. Vila 1995. Aves y Mamíferos Marinos de Santa Cruz, recopilación de los relevamientos realizados entre 1986 y 1994. In Boletín Técnico de la Fundación Vida Silvestre Argentina N²6:1-51. Fundación Vida Silvestre Argentina.

Piedra M., P. Costa \& P. Franco-Fraguas 2006. Ballena franca Eubalaena australis en la costa atlántica uruguaya. In: Bases para la conservación y el manejo de la costa uruguaya. (R. Menafra, L. Rodriguez-Gallego, F. Scarabino \& D. Cconde, Eds.). Vida Silvestre(Sociedad Uruguaya para la Conservación de la Naturaleza).

Rice D.W. 1998. Marine mammals of the world: systematics and distribution. Society for Marine Mammalogy, Lawrence, KS.

Richards R. 1994. Into the South Seas. The Southern Whale Fishery Comes of Age on the Brazil Banks 1765 to 1812. The Paremata Press, Wellington.

Rosenbaum H.C., R.L. Brownell-JR, M.W. Brown, C. Schaeff, V. Portway, B.N. White, S. Malik,
L.A. Pastene, N.J. Patenaude, C.S. Baker, M. Goto, P.B. Best, P.J. Clapham, P. Hamilton, M. Moore, R. Payne, V. Rowntree, C.T. Tynan, J.L. Bannister \& R. DeSalle 2000. Worldwide genetic differentiation of Eubalaena: questioning the number of right whale species. Molecular Ecology 9: 1793-1802.

Santillán L., M. Roca, M. Apaza, L.R. de Oliveira \& K. Ontón 2004. New record of mother-calf pair of southern right whale, Eubalaena australis, off the Peruvian coast. Latin American Journal of Aquatic Mammals 3 (1): 83-84.

Townsend C.H. 1935. The distribution of certain whales as shown by logbook records of American whaleships. Zoologica 19 1-50.

Van Waerebeek K., J. Reyes \& C. Aranda 1992. Southern right whales (Eubalaena australis) off southern Peru. Marine Mammal Science 8 (1): 86-88.

Van Waerebeek K., J.C. Reyes \& M.-F. Van Bressem 1998. Sighting of a mother-calf pair of southern right whale Eubalaena australis in Peruvian waters. Estudios Oceanológicos 17:105-107.

Venegas C. 1996. Estimacion de la densidad poblacional, mediante transectos aéreos en línea, de la tunina overa Cephalorhynchus commersonii en el Estrecho de Magallanes. Anales Instituto Patagonia Serie Cs. Nat. (Chile) 24:41-48.

Venegas C. \& A. Atalah 1987. Prospección aérea otoñal de tuninas overas en el estrecho de Magallanes. Anales Instituto Patagonia Serie Cs. Nat. (Chile) 18: 69-75. 